УДК 340.1

DOI https:/ / doi.org/10.32837 / yuv.v0i3.1962

\author{
Р. Марцінків, \\ аспірант \\ Університету Короля Данила
}

\title{
ВИЗНАЧЕННЯ ПРАВОВОГО СТАТУСУ ТА ДІЯЛЬНОСТІ СЛУЖБИ БЕЗПЕКИ ОРГАНІЗАЦІЇ УКРАЇНСЬКИХ НАЦІОНАЛІСТІВ
}

В українській традиції державотворення є чимало питань, які викликають дискусію серед науковців і мають високий суспільний резонанс. Існують і проблеми, які набувають політичного забарвлення, що ще більше ускладнює їх розуміння, об'єктивне сприйняття i унеможливлює творення цілісної концепції становлення національної держави.

Однією з таких тем є діяльність Організації українських націоналістів та їі окремих органів, які за своїм статусом і функціональним спрямуванням були державницькими аналогами сучасних органів виконавчої влади. Посилений інтерес у цьому плані викликає діяльність Служби безпеки (далі - СБ ОУН) - правоохоронного, розвідувального і контррозвідувального органу, який володів судовими повноваженнями, а також займався ідеологічною роботою і пропагандою серед мирного населення.

Прийняття у квітні 2015 року Закону «Про правовий статус і вшанування пам'яті борців за незалежність України у XX столітті» поклало початок визнанню та легітимізаціi учасників національно-визвольного руху 1940-1950-х рр., за якими 3 радянських часів було закріплено тавро колаборантів. 3 моменту прийняття цього закону усі подальші наукові дискусії стосовно статусу ОУН як організації, щодо діяльності іiі владних інституцій відбувалися у виключній площині істориків, а також були об'єктом політичних спекуляцій.
На жаль, належної правової оцінки статусу і дій ОУН не надано, що і призводить до численних спекуляцій і політичних зловживань.

Загалом в українській історико-правовій науці інтерес до вивчення цієї проблеми посилився протягом останнього десятиліття. Так, важливими є наукові розвідки В. Кубіка [6], П. Лепісевич [7], I. Мамонтова [8], В. Ухача [15] та інших. Багато уваги проблемі присвятили вітчизняні історики, дослідники діяльності силових спецслужб, зокрема Г. Биструхіна, Д. Вєдєнєєва, В. В'ятрович, О. Лисенко, I. Мамонтова, В. Ухач, В. Федоренко та інші.

Метою цього дослідження є визначення правового статусу Організаціі Українських Націоналістів і діяльності Служби безпеки як силового і контррозвідувального органу.

Розгляд статусу СБ ОУН, на нашу думку, доцільно розглядати в контексті діяльності всієї ОУН, оскільки згаданий силовий орган виконував низку важливих функцій - від розвідувальної до просвітницької [14]. При цьому пошук правової оцінки діяльності СБ ОУН можливий тільки в умовах визначення ключових дискусійних питань, які виникають в середовищі українських та іноземних вчених, а також низки законодавчих актів, які регулюють статус учасників націоналістичного руху.

Загалом домінуючими $є$ кілька наукових концепцій, довкола яких ведуться дискусії стосовно правового 
статусу і діяльності ОУН у роки Другої світової війни та повоєнні десятиліття. Так, Н. Довганик [3] виокремив три проблемні аспекти, які відображають сучасні наукові тенденції стосовно статусу ОУН. Перша дискусійна концепція стосується визнання вояків УПА «бандформуваннями» (концепція утверджена в радянськи період і мала на меті нівелювати ідею українського національно-визвольного руху).

Протилежною до цієї концепції є сучасний підхід до кваліфікації членів ОУН як партизанів, що цілком відповідає нормам сучасного міжнародного гуманітарного права. Так, згідно п. 48 Наказу Міністерства оборони України «Про затвердження Інструкції про порядок виконання норм міжнародного гуманітарного права у Збройних Силах України» від 23.03.2017, «партизани - учасники недержавних військових об'єднань, які не належать до регулярної армії, військових загонів, що воюють проти наявної у країні влади (політичного чи військового режиму) або окупаційного режиму ворожої країни» [11].

$\mathrm{y}$ цьому випадку важливим $€$ питання, чи була ОУН і ї бойові підрозділи військовими об’єднаннями. Однозначно, що так. Стосовно воюючої сторони, то загони ОУН і їхній силовий спеціальний орган СБ спрямовували свою боротьбу як проти радянських органів влади, які окупували західноукраїнські землі у вересні 1939 року, так і проти німецьких окупаційних військ, які виступили категорично проти бажання відновлення української державності.

Час створення СБ ОУН датується початком 1939 року [1], тобто в момент, коли Галичина була складником Польської держави. Виразна антирадянська діяльність розпочалася тільки після вбивства спецагентом НКВД П. Судоплатовим засновника і керівника ОУН Є. Коновальця [9, с. $46 ; 14$, с. 63]. 3 моменту свого створення ОУН і Служба безпеки, якщо і були нелегальними організаці- ями, то тільки у складі Польщі, а їх антирадянська діяльність була виявом державницьких устремлінь і спробою відновити українську державу.

СБ ОУН був повноцінним органом виконавчої влади, який здійснював контррозвідувальну діяльність проти польських, радянських, а після 1941 року - німецьких спецслужб. Усі діï, які здійснювали члени СБ ОУН у період з вересня 1939 до червня 1941 року, були цілком виправданими, оскільки вони єдині, хто чинив опір насильницькій радянізації регіону, протистояли актам терору та депортації українців, які виступали проти радянської влади.

Друга дискусійна концепція передбачає визнання представників українського націоналістичного підпілля «поплічниками фашистів», тобто колаборантами. Протилежною є думка, що український визвольний рух середини $\mathrm{XX}$ ст. був державницького типу. Стосовно колабораціонізму, то застосування цього поняття $€$ виправданим щодо осіб, які співпрацювали з німецькими окупантами в роки Другої світової війни. Однозначно, що серед окупованих німцями народів Європи були ті, які добровільно співпрацювали 3 ними. Такі колаборанти були серед французів, поляків, українців, білорусів, росіян, чехів та інших. Ці процеси $€$ закономірними і здебільшого зумовлюються політичними і психологічними потребами людей.

Якщо розглядати колабораціонізм ширше, то це «співпраця населення або громадян держави 3 ворогом в інтересах ворога-загарбника на шкоду самій державі чи їі союзникам, участь у переслідуванні патріотів країни, громадянином якої є колаборант» [4]. 3 цього трактування однозначно можна зробити висновок, що представники ОУН і СБ не були колаборантами, оскільки не вчиняли шкоди власній державі.

Проголошена 30 червня 1941 року Українська Соборна Самостійна Держава стала об’єктом захисту з боку 
СБ ОУН від німецьких і радянських спецслужб. Більше того, саме німці після арешту лідерів націоналістичного підпілля перетворилися на ключових противників СБ ОУН і залишалися такими до середини 1944 року.

Після 1944 року основний акцент у роботі ОУН спрямовувався проти радянської влади. 3 цією метою у листопаді 1943 року на І-й Конференції поневолених народів Східної Європи і Азії на Волині було створено Антибільшовицький блок народів [5]. Через кілька місяців представники ОУН і лідери Антибільшовицького блоку народів видали низку відозв до інших народів СРСР (узбеків, туркмен, казахів, башкирів, калмиків, удмуртів, волзьких татар та інших), які знаходилися в німецькому полоні і при поверненні могли б вплинути на своїх співвітчизників.

Як зауважує П. Кралюк, такі звернення давали реальні практичні результати, оскільки вже 29-30 вересня 1943 року на бік до ОУН і УПА перейшов відділ азербайджанців-червоноармійців, які базувалися у Здолбунові (160 осіб) [5]. Згодом у складі УПА з'явилися національні частини народів Сходу [5]. Тобто, ОУН не була колаборантом німецьких окупантів, а повноцінною державницькою інституцією, яка не тільки займалася організацією владних процесів на контрольованій нею території, а й здійснювала активну агітаційну діяльність серед інших народів СРСР, апелюючи до їх національної та історичної пам'яті.

Третя дискусійна проблема стосується можливості визнання членів ОУН «воюючою стороною» часів Другої світової війни. Ще 22 жовтня 1993 року Верховна Рада України прийняла Закон «Про статус ветеранів війни, гарантії їх соціального захисту» [13]. Специфікою закону було те, що в ньому закладалися часові межі дотримання законності статусу учасників бойових дій членів ОУН. Верхньою межею визначали 1944 рік - час звільнення УРСР від нацистських загарбників і відновлення радянської влади.

Така норма була однозначним рудиментом, адже формально і юридично заперечувала державницькі устремління українців і закріплювала за членами націоналістичного руху опору, які боролися проти органів HKBC, статус незаконних збройних формувань і ворогів держави. Протягом наступних десятиліть дискусійним залишалося питання правового статусу членів ОУН, які боролися проти радянської влади після 1944 року. Тільки у березні 2018 року з п. 16 згаданого закону було вилучено норму про часові межі і надано статус учасників бойових дій особам, «які брали участь у всіх формах збройної боротьби за незалежність України у ХX столітті в складі Української повстанської армії, Української повстанчої армії отамана Тараса Боровця (Бульби) «Поліської Січі», Української народної революційної арміі (УНРА), Організації народної оборони «Карпатська Січ», Української військової організації (УВО), збройних підрозділів Організації україньких націоналістів» [13].

Такі правки стали можливими внаслідок прийняття у 2015 році Закону України «Про правовий статус і вшанування пам'яті борців за незалежність України у XX столітті» (далі - Закону) [12]. Прийняття Закону було результатом сукупності різноманітних політичних і суспільних чинників, які активізувалися в умовах російської військової агресії на Сході України та окупації Криму.

Преамбула Закону містить важливі для української історико-правової науки норми про необхідність «визнання учасників боротьби за незалежність України у XX столітті головними суб'єктами боротьби за відновлення державної незалежності України борцями за незалежність України у XX столітті, встановлення правового статусу борців за незалежність України у XX столітті, 
визначення права такої категорії осіб на отримання державних i муніципальних соціальних гарантій» [12]. Таке формулювання надало юридичного статусу Акту відновлення української державності 30 червня 1941 року, а також закріплювало за ОУН та їі владними інституціями статус офіційних державних формувань.

Однією з вірогідних причин такого тривалого зволікання із визнанням членів ОУН і ії силових структур учасниками бойових дій, окрім політичної, була і певна «історична помилка», яка стосується формулювання подій 1941-1945 років, які в радянській історіографії отримали назву «Велика вітчизняна війна», хоча для українців це була частина Другої світової війни. Як слушно зауважує П. Лепісевич, «Для тих, хто ототожнює Другу світову війну з Великою Вітчизняною, ОУН (б) i УПА не є іï учасниками» [7, с. 30]. Справедливим є також формулювання, що і самі члени українського націоналістичного підпілля не вважали себе учасниками «Великої Вітчизняної війни» [7, с. 30].

Важливою дискусійною проблемою є питання реабілітації учасників націоналістичного підпілля, які в радянський період були визнані зрадниками та відбули різні терміни ув'язнення в концентраційних таборах Сибіру. Необхідність реабілітації учасників націоналістичного підпілля обгрунтовується тим, що згідно трьох вище наведених проблем вони виступали за відновлення національної державності, а ї дії можна кваліфікувати як партизанські, говорячи про час Другої світової війни.

Повоєнні роки також кваліфікуються як час ідеологічного протистояння 3 радянською владою. Ці тези підтверджені у «Історичному висновку про діяльність ОУН-УПА», підготовленому колективом українських істориків під керівництвом С. Кульчицького. Положення висновку були враховані у проекті Закону 2000 року «Про відновлення історичної справед- ливості у боротьбі за свободу і незалежність української держави в період з 1939 до середини 50-х років». Однак він так і залишився тільки проектом, а у 2001 році група розробників «Історичного висновку» втратила фінансування і не змогла проводити подальші дослідження [2, с. 122]. Подібне рішення мало виключно політичний контекст і натепер залишається не вирішеним.

Тільки у березні 2018 року було внесено правки до Закону України «Про реабілітацію жертв політичних репресій в Україні», згідно якого реабілітації підлягали учасники націоналістичного підпілля, в тому числі й члени СБ ОУН. За підрахунками Ю. Шухевича, станом на 2018 рік таких осіб було понад 1,2 тисячі [10].

Визначаючи правовий статус діяльності Служби безпеки ОУН, можна констатувати, що:

1) існують аргументовані факти, які доводять, що ОУН та їі силові органи, в тому числі й СБ, діяли в умовах боротьби за відродження української національної держави;

2) у період 1941-1944 років вони вели збройне протистояння 3 радянськими, німецькими військовими i польським націоналістичним підпіллям, що не відповідає усталеному в радянський період концепту колаборації з нацистською Німеччиною;

3) в умовах незалежності в Україні було прийнято низку законів i нормативних актів, які закріплюють за членами ОУН статус учасників бойових дій, а також реабілітують засуджених радянською владою за антидержавну діяльність. Однак через «політичність» деяких законів ї норми є недосконалими і вимагають редагування;

4) об'єктивності в питанні визначення правового статусу і діяльності ОУН можна досягнути тільки після врахування політичних, історичних та юридичних аспектів, а це вимагає залучення науковців і політиків до подібної роботи. 
У статті здійснюеться правова оцінка діяльності Служби безпеки Організацї українських націоналістів. Виокремлюються ключові дискусійні питання, які перешкоджають чіткому кваліфікуванню ОУН $і$ ï силових органів як державницьких. Наводяться аргументи, які заперечують застосування до СБ ОУН таких категорій як «бандформування», «колаборанти», «зрадники».

Наводяться факти, щзо підтверджують відповідність учасників національного визвольного руху середини XX cm. нормам міннародного гуманітарного права, які дозволяють кваліфікувати їх як партизанів. На підставі історичних фактів визначаються історико-правові аспекти створення та функиіонування СБ ОУН, а також чинники, які дозволяють кваліфікувати ї як державну інституцію, що в своїх діях, в тому числі ü силових, керувалася насамперед бажанням відродити національну державність $i$ захистити національні інтереси.

Аналізуються чинні норми національного законодавства, які визначають статус вояків ОУН як «учасників бойових дій», а також визнають їх бориями за відродження національної державності середини XX ст. Одночасно вказуеться на численні прорахунки та рудименти в законодавстві, зокрема в частині реабілітації учасників визвольних змагань, а також подолання суспільного протистояння стосовно проблеми правового стаmусу СБ ОУН.

Визнаючи дії ОУН загалом $i$ СБ ОУН зокрема як дії, спрямованіна відродження національної державності, що була офіційно проголошена 30 червня 1941 року, вказується, щзо ияя інституція володіє всіма атрибутами виконавчого органу влади з чітким набором оперативних функиій. Навіть в умовах від- сутності національної державності i протистояння з більшовицькими спецслужбами СБ ОУН ефективно виконувала свої функиії, хоча окремі ї̈ діï (винесення каральних вироків) не завжди були гуманними.

Як висновок визнається, що, окрім закріплення правового статусу ОУН, важлива $i$ просвітницька, виховна ци освітня діяльності стосовно популяризації заангажованих у радянський період фактів національної історії державотворення.

Ключові слова: Служба безпеки, Організація українських націоналістів, правовий статус, учасники бойових дій, законодавство.

Martsinkiv R. Determination of the legal status and activities of the Security Service of the Organization of Ukrainian Nationalists

The article provides a legal assessment of the activities of the Security Service of the Organization of Ukrainian Nationalists. The key issues of discussion are highlighted, which hinder the clear qualification of the OUN and its law enforcement agencies as state bodies. Arguments are made that deny the use of such categories as "gangs", "collaborators", "traitors" in relation to the OUN Security Service. The facts confirming the conformity of the participants of the national liberation movement of the middle of the XX century are given.

Norms of international humanitarian law, which allow to qualify them as guerrillas. On the basis of historical facts, the historical and legal aspects of the creation and functioning of the OUN Security Council are determined, as well as the factors that allow it to be qualified as a state institution, which in its actions, including law enforcement, was guided primarily by the desire to revive national statehood. 
The current norms of national legislation are analyzed, which define the status of OUN soldiers as "participants in hostilities", as well as recognize them as fighters for the revival of national statehood in the middle of the twentieth century. At the same time, it points to numerous miscalculations and rudiments in the legislation, in particular in the rehabilitation of participants in the liberation struggle, as well as overcoming public opposition to the issue of the legal status of the OUN Security Council.

Recognizing the actions of the OUN in general and the OUN Security Council in particular, as actions aimed at reviving national statehood, which was officially proclaimed on June 30, 1941, it is stated that this institution has all the attributes of an executive body with a clear set of operational functions. Even in the absence of national statehood and confrontation with the Bolshevik secret services, the OUN Security Service performed its functions effectively, although some of its actions (sentencing) were not always humane.

In conclusion, it is recognized that in addition to consolidating the legal status of the OUN, it is important and educational, upbringing and educational activities to promote the facts of the national history of state formation involved in the Soviet period.

Key words: Security Service, Organization of Ukrainian Nationalists, legal status, participants in hostilities, legislation.

\section{Література}

1. Грабовський C. Iнтерв'ю 3 B. Куком $i$ B. Понаморьовим. URL: wrw.RadioSvoboda.org.

2. Гриценко О. Президенти і пам'ять. Політика пам'яті президентів України (1994-2014): підірунтя, послання, реалізація, результати. К. : «К.I.C.», 2017. 1136 с.

3. Довганик H.М. Український національно-визвольний рух у роки Другої світової війни. Українське суспільство на шляху до політичної нації: історія $i$ сучасність : колективна монографія. К. : KHEУ, 2014.

4. Колабораціонізм. URL: https:// uk.wikipedia.org / wiki / Колабораціонізм.

5. Кралюк П. ОУН, УПА та АБН: українські націоналісти співпрацювали з різними народами. URL: https: / / шшш. radiosvoboda.org / a /30617332.html.

6. Кубік В.С. Організаційно-правові аспекти вщанування ОУН і УПА на сучасному етапі державотворення в Україні. Держава у теорії і практиці українського націоналізму. Мат-ли VI Всеукр. наук. конф. $з$ міжнар. участю. Івано-Франківськ, 26-27 червня 2015 року / Наук. ред. О.М. Сич. Івано-Франківськ : Місто HB, 2015. C. 206-209.

7. Лепісевич П.М. Протистояння організації українських націоналістів i радянської влади в роки Другої світової війни та у повоєнний період: історико-правовий аспект. Науковий вісник Львівського державного університету внутрішніх справ. Серія: Юридична. 2017. Bun. 1. C. 28-39. URL: http:// nbuv.gov.ua/UJRN/Nvlduvs_2017_1_6.

8. Мамонтов I.О. Правові особливості Закону України «Про правовий статус $i$ вшанування пам 'яті бориів за незалежність України у ХX столітті» від 09.04.2015 року № 314-УШ. Держава у теорії $і$ практиці українського націоналізму. Мат-ли VI Всеукр. наук. конф. з міжнар. участю. Івано-Франківськ, 26-27 червня 2015 року / Наук. ред. O.M. Сич. Івано-Франківськ : Місто НВ, 2015. C. 242-248.

9. Матеріали та документи Служби безпеки ОУН (б) у 1940-х рр. / Упоряд.: О.Є. Лисенко, І.К. Патриляк. К. : Iн-m історії України НАН України, 2003. 254 с.

10. Москвичова А. УБД для УПА: що означають ухвалені парламентом поправкu. URL: https: / / wшw. radiosvoboda.org / a / ubd-dlia-upa-shchooznachajut-popravky/29641827.html.

11. Про затвердження Інструкції про порядок виконання норм міжнародного гуманітарного права у Збройних Силах України : наказ Міністерства внутрішніх справ України № 164 від 23.03.2017. URL: https://zakon.rada.gov.ua/laws/ show / z0704-17\#Text.

12. Про правовий статус $i$ вшанування пам'яті бориів за незалежність України у ХХ столітті : Закон України. 


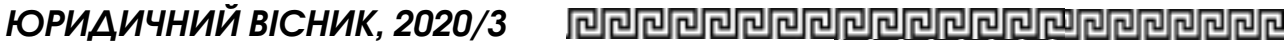

Відомості Верховної Ради (ВВР), 2015, № 25, cm. 190. URL: https:// zakon.rada.gov.ua/laws/show/314-19\# Text.

13. Про статус ветеранів війни, гарантії їх соціального захисту : Закон України. Відомості Верховної Ради України $(B B P), 1993$, № 45, cm. 425. URL: https: / / zakon.rada.gov.ua/laws / show/3551-12\#Text.

14. Спосіб Д.П. Правове становище $i$ організація діяльності Служби безпеки
ОУН (б). Науково-інформащійний вісник Івано-Франківського університету права імені Короля Данила Галицького. Серія: Право. 2019. № 8. С. 62-70.

15. Ухач В.3. Правова оиінка боротьби УПА у світлі національного законодавства. URL: http: / / www.legalactivity.com.ua/ index.php?option $=$ com_content\&view $=$ article $\& i d=1736 \% 3$ A091217-14\& catid $=197 \% 3 A 1-1$ $22017 \&$ Itemid $=244 \&$ lang $=e n$. 